\title{
The Effect of Labour Union's Formation of Cooperative Societies and Provision of Transportation Facilities on Maritime Workers In Nigeria
}

\author{
${ }^{1}$ Stephen Adi Odey (Ph.D), ${ }^{2}$ Josephat Owan Emeka (Ph.D), ${ }^{3}$ Frank Ayade \\ (Ph.D) \\ ${ }^{1,2}$ Department of SociologyUniversity of Calabar Calabar, Nigeria. \\ ${ }^{3}$ University of Port Harcourt Rivers State.
}

\begin{abstract}
Considerable controversy surrounds the formation of cooperative thrift and provision of transportation facilities undertaken by the maritime workers' union as means of improving members welfare. Our analysis of this study draws evidence from 1000 respondents. A self-constructed 45 item questionnaire on a four scale was used for data collection. Overall, findings reveals that a significant positive relationship exists between union's formation of cooperative societies and the provision of transportation facilities for union members. The study recommends that along with raising the welfare of its members which was found to be generally low, labour unions should rise to the responsibility of encouraging their members to join cooperative thrift and that union leaders should be credible individuals who seek the welfare of its members and not their personal interest.
\end{abstract}

\section{Introduction}

Labour unions have developed from the belief that workers everywhere, in increasing complex societies, could only maintain and improve their lot by organizing together with their colleagues to form a corporate body that could seek for them adequately.

In recent times, the relationship that has existed between the employer and the employee has not been cordial. Each of these entities have always borne grudges against the other suggesting that the opposite partner is not living up to expectations. Maritime workers have always complained of amount they are paying as rent, and the prices of such staples as garri, rice and yam (Irabor, 2009).

According to Onitiri (2007) despite the improvement that had occurred in transportation over the years in the area of bus service, maritime workers trekked several kilometers to the ports to carry out their functions. There was still a lot to be done. Buses are few and there have been too much congestions at the bus stops. They were most often late to work which often led to low productivity.

In Nigeria, the economic pace is dictated by government and the large corporations - and the terms and conditions of service set by them not only influence the small enterprise and the single employer must conform to or at least aim to attain (Dalhatu, 2007). Fajana (1995) aptly remarked that while the single employer has always been economically stronger than the workers in terms of bargaining the terms of employment, the position of the modern corporation and the state is even more overwhelming. This has emphasized the need today, even more then in the past for workers to organize as a means to effectively enhance their conditions of employment. This study is not concerned with what the employer can do for its workers and vice versa as this has always been an infinite issue in which no party can admit satisfaction.

The study examines the roles that labour unions can play in enhancing the welfare of their members. The hypotheses formulated for the study were:

Ho: $\quad$ There is no significant effect of union's formation of corporative societies on worker's welfare.

Ho: There is no significant relationship between union's provision of transportation facilities and workers' welfare.

\section{Literature Review}

Some years back when unions began to be more visibly sensitive and reactive to the welfare of its members, many stakeholders were more confused than convinced about the direction of economic events locally, regionally, and beyond. According to Odey and Young (2008) there is now a consensus and convergence of scholarly thought about the roles of labour unions in enhancing the welfare its members. 
The Effect Of Labour Union's Formation Of Cooperative Societies And Provision Of

\section{Trade Unions' Formation of Cooperative Societies and Enhancement of Workers' Welfare}

Cooperative societies are member - based organizations that help members to address economic problems. They are not banking institutions because of the goals (Adegeye, 1999). The ultimate goal is to encourage thrift among members and to meet credit needs of people who might otherwise fall prey to loan sharks and other predatory lenders (Adegeye, 1994). These societies mobilize local savings and administer credit to members, thereby encouraging thrift and entrepreneurial activities.

Adekunle and Henson (2007) in a study on the role of cooperatives reveals that labour unions because of its determination to enhance worker's welfare can only initiate or encourage the formation of corporative societies that can promote their welfare but cannot exercise control over the societies neither can the cooperative societies.

Hann, louter and Gerard (2003) observed that for the union to really reach the height of members welfare, the union should not only initiate the formation of a corporative society in organization but should also encourage or urge members (workers) to join. Adekunle and Henson (2007) identified the following ways by which corporative societies can enhance workers welfare:

i) Grant low interest loans to members.

ii) Provide monthly cash advance in case of emergencies or any unexpected cash shortage which is renewed with only $7 \%$ interest.

iii) Asset acquisition: Members are provided with upon request, household equipment including refrigerators, gas cookers, television, cars etc and the amount involved is recovered from the members' salaries in small installments.

iv) Purchase of foodstuff, to ease hardship associated with cost of goods and food stuffing during the yuletide period and amount used in purchase of these items is spread over a period of 3 months.

Several empirical studies (Eaton 1999, Suendsen and Suendsen 2004, Van, 2005) have confirmed that cooperative societies could serve as an important mechanism for the support of groups who are alert to opportunities in their environment, some individual feel comfortable borrowing from the informal sector.

Fig.l: Tree diagram showing types of cooperative societies

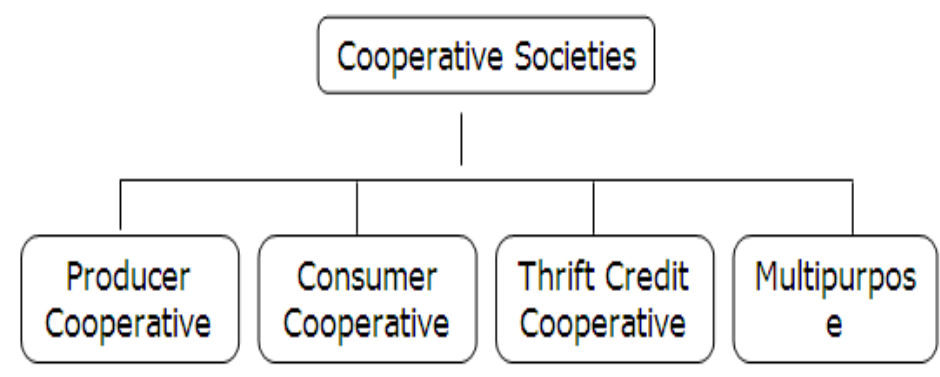

1. Procurement

Production inputs

2. Hiring facilities

3. Marketing of outputs

4. Financing

5. Primary \& secondary

Production
1. Wholesaling 1. Mobilizing of

2. Retailing

saving

2. Provision of credit facilities

Viable cooperatives are associated with greater financial output, higher incomes, better indicators of access to health services and greater wage income opportunities. The function of cooperative societies has important implication for the alleviation of poverty.

\section{Trade union's provision of transportation facilities and workers' welfare in Nigeria.}

The spatial differences of phenomena on the earth's surface means that no one part of it is capable of providing all the products people need and so goods can only be obtained by either moving one's self to the point of supply or moving the goods to point of demand and this can only be done by transport (Akpoghomeh, 2003).

Public infrastructure over the years has been the responsibility of governments of all persuasions have increasingly sought private sector involvement in the supply of transport infrastructure and services (Okoko, 
2006). The reason is that the private sector is often believed to be inherently more efficient than the public sector and it can build and operate facilities at less cost than the public sector.

The fact that transport is critical to the development effort has long been recognized. But inappropriately designed transport strategies and programme can result in networks and services that aggravate the condition of the poor, harm the environment, ignore the changing needs of users and exceed the capacity of public funds (Gwillian and Shalizi, 1996). For Adenji (1987), the global wind of change blowing in the direction of privatization and commercialization is steadily taking roots in the provision of transportation facilities by government. It is within this context of change that economically efficient changes are being sought for ownership, provision, funding and management of transport services for workers. This is with the ultimate intention of making transportation affordable to workers and more responsible to changing needs and dict0ars of economic reality.

According to Okoso (2006), economic and other social activities and services rely mostly entirely on transportation system for the physical movement of people, goods and services from one location or point to another. Onitiri (2007), reveals that labour unions play a key role in the provision of transportation facilities to offices to designated routes at a subsidized rate. These ensure improvement in job performance as workers are conveyed within a designated route to a designated location where they are saved from prolonged waiting as noticeable in cities like Lagos, Abuja and Port Harcourt.

Ahmed (1976), cited in Button (1993) aptly remarked that inadequacy of transport facilities is one of the major causes of lateness to work by workers in organization. There is thus justification to view transportation facilities as an attractor variable to socio-economic development and services.

Transportation permits the geographical separation of employment from leisure, it increases the life style options open to workers giving them a choice among residential locations away from cities although involving a heavy commitment to travel (Klatzel, 2000).

\section{Methodology and data analysis}

In order to undertake an in-depth investigation of trade unionism and the enhancement of workers' welfare in Eastern Ports, the survey research Method was adopted.

The population of this study comprises of workers in eastern Ports of Nigeria. Eastern Ports are made up of Calabar, Port Harcourt, Warry and Onne Ports and statistics available at the headquarters of the ports show that there were four thousand, one hundred and ten (4110) workers in all Eastern Ports of Nigeria. Sample size per ports was decided based on the number of workers per port.

Table 1: Maritime Workers in Eastern Ports, Nigeria (2009 - 2011)

\begin{tabular}{|c|c|c|c|}
\hline $\mathbf{S} / \mathbf{N}$ & Name of Port & No. of Workers & $\%$ \\
\hline \multirow[t]{5}{*}{1.} & Calabar & 1,958 & 47 \\
\hline & Port Harcourt & 935 & 22.75 \\
\hline & Warri & 730 & 17.76 \\
\hline & Onne & 487 & 11.85 \\
\hline & Total & 4110 & \\
\hline
\end{tabular}

Source: NPA Statistics Department, 2011

After deciding the sample per port, the workers in each port were categorized into male and female to enable the researcher select a representative sample taking into consideration the respondents' sex using purposive sampling method.

The sample of this study was made up of one thousand (1000) respondents selected from the four Easter Ports of Nigeria. Of this sample 650 workers $(65 \%)$ were male and 350 workers $(35 \%)$ were female. The questionnaire was divided into two sections. Section A had to do with the respondents bio-data demographic information such as sex, age, educational, position and salary scale. Section B was made up of forty five (45) items on a four - point scale. Measure that sought worker's opinion on the five independent sub-variables, (union's information of cooperative societies and union's provision of transportation facilities for members) and the four dependent variables (namely award of scholarships to members children, festivity packages, soft loans to members and financial assistance. Each independent variable and six items while the dependent variable (workers welfare) had four items on the questionnaire.

\section{Test of Hypotheses}

\section{Hypothesis I}

Hypothesis I states that there is no significant relationship between the union's formation of cooperative societies and worker's welfare. In this hypothesis the independent variable is union's formation of cooperative societies which the dependent variable worker's welfare. The variables involved were both 
The Effect Of Labour Union's Formation Of Cooperative Societies And Provision Of measured continuously. In this way, Pearson Product Moment Correlation Analysis was considered the most applicable test tool for its analysis. The summary of this is shown in Table 2.

Table 2

Pearson Product Moment Correlation Analysis of the relationship between union's formation of cooperative societies and workers' welfare.

\begin{tabular}{lcccccc}
\hline \multicolumn{1}{c}{ Variable } & $\mathbf{x}$ & SD & $\begin{array}{c}\sum \mathbf{y} \\
\mathbf{x}\end{array}$ & $\begin{array}{c}\sum \mathbf{y}^{2} \\
\sum \mathbf{x}^{2}\end{array}$ & $\sum \mathbf{x y}$ & $\mathbf{r x y}$ \\
\hline Formation of cooperative & 14.46 & 3.20 & 19548 & 49837 & 1793587 & $.368^{*}$ \\
Workers welfare & 29.63 & 6.17 & 82704 & 234125 & & \\
\hline
\end{tabular}

$* \mathrm{P}<.05, \mathrm{df}=997$, critical $\mathrm{r}=0.062$.

As shown in Table 2 the calculated $r$ - value of which represents the observed relationship between union's formation of corporative societies and workers' welfare is 0.368 . This is greater than the critical $r-$ value of 0.062 at .05 level of significance with 998 degree of freedom. On the basis of this, the null hypothesis was rejected while the alternate hypothesis is retained. This therefore means that a significant positive relationship exists between unions formation of cooperative societies and workers' welfare.

\section{Hypothesis II}

In the null form, the second hypothesis, stated that there is no significant influence of unions' provision of transportation facilities on workers' welfare. Here, the independent variable is the extent of unions' provision of transportation facilities. This was assigned three independent levels in this study (high, moderate and low). The dependent variable on the other hand is workers' welfare which was measured continuously. The mean score (x) and standard deviation (SD) of the three categories of respondents classified in terms of their perception of union's provision of transportation facilities were obtained for comparison. One - way analysis of variance was employed to test the hypothesis. The result of the analysis is as presented in Table 3.

Table 3

One - way analysis of variance of the influence of union's provision of transportation facilities on workers' welfare.

\begin{tabular}{ccccc}
\hline Group & $\begin{array}{c}\text { Provision of } \\
\text { Transport }\end{array}$ & $\mathbf{n}$ & $\overline{\mathbf{x}}$ & SD \\
\hline 1 & Hogh & 288 & 29.64 & 4.66 \\
2 & Moderate & 317 & 28.09 & 5.23 \\
3 & Low & 395 & 27.26 & 5.84 \\
Source of variation & SS & df & Ms & F \\
Between Groups & 68.48 & -2 & 34.24 & $4.16^{*}$ \\
Within groups & & & & \\
& 8205.31 & 997 & 82.23 & \\
\hline *P< $05, \mathrm{df}=2$ and 997, critical F $=3.00$ & Total & 8273.79 & 999 &
\end{tabular}

As shown in Table 3 the calculated F-value of 4.16 obtained. This represents the observed influence of union's provision of transportation facilities on workers' welfare. This calculated F-ratio was found to be greater than the critical F-ratio of 3.00 at 0.05 level of significance with 2 and 997 degrees of freedom. Thus, the null hypothesis was rejected while the alternate is retained. The interpretation of this is that the measure of union's provision of transportation facilities exerts significant influence on workers' welfare. To determine exactly the group that brings about the difference, a multiple pair-wise post hoc test was considered necessary. Fisher's least significance difference (LSD) post hoc test was performed on this. This results obtained are shown in Table 4.

Table 4

Fishers' least significant difference of post hoc test of the influence of union's provision of transportation facilities on workers' welfare.

\begin{tabular}{|c|c|c|c|c|}
\hline Group & Provision of transport & $\begin{array}{c}\mathbf{1} \\
(\mathbf{n = 2 8 8})\end{array}$ & $\begin{array}{c}\mathbf{2} \\
(\mathbf{n = 3 1 7})\end{array}$ & $\begin{array}{c}\mathbf{3} \\
(\mathbf{n = 3 9 5})\end{array}$ \\
\hline 1 & High & $29.64^{\mathrm{a}}$ & $1.55^{\mathrm{b}}$ & 2.38 \\
2 & Moderate & $6.64^{{ }^{*} \mathrm{c}}$ & 28.09 & 0.83 \\
3 & Low & $10.71^{*}$ & $3.84^{*}$ & 27.26 \\
& Msw $=8.23$ & & & \\
\hline
\end{tabular}


(a) Group means are on the diagonal

(b) Difference between group means are above the diagonal

(c) Fishers' least significant difference test values are below the diagonal.

$* \mathrm{P}<.05, \mathrm{df}=998$, critical $\mathrm{t}=1.96$

In table 4, significant t-values are observed between groups 1 and 2, 2 and 3 and between group 1 and 3. In each case, the calculated $t$ - value was found to be greater than the critical t-value of 1.96 at 0.05 level of significance with 998 degree of freedom. This means that the difference between each pair of group is significant. This is interpreted to mean that any change in the extent of provision of transportation facilities exerts a significant influence on workers' welfare. Thus, the null hypothesis guiding this aspect of the investigation has to be rejected in totality.

\section{Discussion of Findings}

The test of the data collected on the first hypothesis was analysed using Pearson Product Moment Correlation Statistics. It was found that there is a significant relationship between the union's formation of cooperative societies and workers' welfare. The relationship which was observed to be positive in nature can be interpreted to mean that as the tendency to form cooperative among union members increases, the welfare accruing to members also increases and vice - versa.

From this finding, it therefore implies that when workers form cooperatives, certain benefits are unveiled to members. In the course of interaction in the societies, certain facts on welfare are made known to members who may not have been exposed to such yet. Thus, the higher the rate of formation of cooperative societies among union members, the better their welfare status and vice versa. This finding agrees with Adegeye (1999) who defined cooperative societies as member - based organization that help members to address economic problems. Thus, the ultimate goal of cooperatives is to encourage thrift among members and to meet credit needs of people who might otherwise fall prey to loan sharks and other predatory lenders.

Lastly, the finding that a positive relationship exists between with the submission of Odey and Young (2008) who observed that through cooperatives, many benefits in terms of welfare accrue to members such as the granting of low interest loan to members, monthly cash advance, assets acquisition and the purchase of food stuff to ease hardship associated with high cost of goods during festive periods. Thus, the formation of cooperative societies enhances workers' welfare in no small measure. This finding is therefore not a derivation from the ideal.

The result of the data collected on the second hypothesis involving the variable of provision of transportation facilities and workers' welfare showed that there is a significant influence of union's provision of transportation facilities on workers' welfare. On the basis of this, the null hypothesis was rejected. This means that the higher the provision of transportation facilities by the union, the better the welfare package to workers and vice versa. This is clearer when one looks at the mean score obtained by the three groups of respondents on the dependent variable of this hypothesis.

This result is not surprising because the key role transportation plays in any economy or any sector of the economy. This finding therefore agrees with the submission of Okoko (2006) that the role of transportation is not limited to merely servicing other things, for it is also often serves as a tool of development of individuals and communities. In other words, economic and other social activities and services rely almost entirely on transportation system for the physical movement of people, goods and services from one location or point to another.

\section{Conclusion}

The results of the study indicates that workers who are members of cooperative thrift and credit societies in the study area were better entrepreneurs than non-members. This may be as a result of the interdependent nature of these societies and provision of accessible credit.

Workers feel comfortable borrowing from the informal sector. Even if the interest rate and collateral of banks is accessible to workers, they way still refuse to borrow from anything called a bank. The name "Bank" may be disincentive for borrowing, so people should be encouraged to do things their own way while a regulatory framework compatible with people's value system is put in place to check exploitation.

Onitiri (2007), maintained as seen in this study that trade unions play a key role in the provision of transportation facilities to members as it provide access to designated routes at a subsidized rate. When this is done, the money that would have been used in this regard is channeled to other areas of needs. In this way, workers' welfare is enhanced. 


\section{References}

[1] Adegete, A. J. (1999). Some observations in financing farmers cooperatives in developing countries. Nigeria Trade Journal, 25(6), $53-55$.

[2] Adegeye S. O. (1940). The cooperative movement in Nigeria: Yesterday, today and tomorrow, Gottingen, Germany Vandenhoeck and Ruprecht.

[3] Adeniji, K. (1997). Factors in union transport (demand and supply): The Ogun State experience. Abeokuta: Ogun State University Press.

[4] Akpoghomeh, O. S. (2003). Transport: Developing analysis and planning. Port Harcourt: Man Printers.

[5] Eaton, J. (1999). The basque workers' cooperatives. Industry Relations Journal 10(3), 1 - 2.

[6] Gwillian, K. \& Shalizi, (1996). Suitable transport, priorities for policy reform. Washington DC: The World Bank.

[7] Hann, J., Louter, K., \& Gerald; G. (2003). Innovative behaviour in India cooperatives. New product development in traditional sectors. London: Longman.

[8] Irabor, O. (2006). Transportation and dockers productivity: A paper presented at dock labour employers conference. Nigerian Ports Authority. Port Harcourt. November 12.

[9] Klatzel, F. (2000). Green roads: Building environmentally, low maintenance rural roads through participation. http://www.

[10] mtnforum /resources/library/klatfooa.htm.

[11] Odey, S. A. \& Young, A. (2008). An appraisal of the Trade Unions (amendment) Act, 2005: Implications and challenges for effective bargaining and industrial conflict resolution. Nigeria Journal of Labour Law and Industrial Relations, $2(2), 81$ - 91.

[12] Okoko, E. (2006). Urban transportation planning and modeling. Akure: Macmillan Printers.

[13] Onitiri, S. (2007). Transportation and workers productivity in the maritime sector. A paper presented at Mills seminar for Nigerian Ports Authority unionists, Ijebu, December, 8. 